Received May 31, 2010

Revised October 13, 2010

Accepted November 29, 2010

\title{
Korean Sovereignty: Eastern and Western Philosophy in the Kaleidoscope of History
}

\author{
KENNETH M. BURKE
}

Throughout history, from obstacles involving foreign invasion and intervention coupled with domestic rivalry, the Korean peninsula struggled to legitimize and protect its sovereignty. This research involves an investigation and analysis of patterns in that history. The article provides a broad examination of Korean political development with interdisciplinary insights into sovereignty while underscoring the need for new approaches and epistemological unity in political philosophy. The Korean peninsula serves as an example of the challenges.

Keywords: Sovereignty, IR Theory, Political Economy, Cultural Dynamics, Korean History 


\section{INTRODUCTION}

W

ith the sweeping currents of change in the international system, questions in international politics center on the shifting nature of sovereignty, particularly given the technological advances and economic paradigms represented by neoliberalism as it dominates the political economy. Theorists in international relations recognize that nowms are changing rapidly with globalization. Globalization and de-globalization refer to the increase or decrease of globalism: "a state of the world involving networks of interdependence," increasing to the extent that sovereignty will be "up for grabs in a way that has not been the case since the seventeenth century," (Keohane, 2002, 193, 213) when the international system witnessed increased globalism not unlike today. In actuality, from a holistic perspective, transformations in norms are nothing new; moreover, dynamic change remains a constant in history. The historical evolution of domestic governance and political and economic relations from ancient times to the modern era, prove that this is true of Korean social organization.

Of late, the factionalism between nationalist discourse and neoliberal, political economic strategies undertaken in Korea exemplify the controversies and debates over sovereignty. In 1994, Kim Young Sam announced plans to globalize Korea "as the country's new vision and development strategy," (Kim and Hong, 2001, 78) following neoliberal trends central to questions over the impact of global integration on national sovereignty. With the consequent paradoxes for national security and economic development cyclical in history, Korea's society knows well the concerns related to the complexities of domestic, regional, and global economic relations. The underlying debates reflect upon ancient ones grounded in the dichotomy between Buddhism, which maintained an informal concept of sovereignty that advocated a collective civil society, and then the institutionalization of the Confucian tradition that associated governing authority with the political elite. Correlated in light of historical struggles and interpretations of Western political concepts by Korean scholars, comparative insights illustrate the past and present-day obstacles to governance accordingly.

Recognizing that Eastern and Western histories face the human condition from different contexts, the point is not to provide for a statistical correlation and covariance of the commonalities, especially as, for example, Buddhism transformed from complex cultural dynamics, evolving customs throughout Asia, and "historical vicissitudes over centuries" (Carter, 1997, 360). Much the same proves true of Western political science, particularly at the intersections between economic and political theory, the domestic state and the international system. Moreover, the study of Buddhism and Confucianism often remains shrouded in legends, especially given the dominant Confucian erudition that became prevalent from the time of the Choson Dynasty in Korea (Jae-ryong, 1999). Acknowledging the downfalls in the generalization of the comparative analysis, a nested case-with- 
in-case design paradigm and holistic method aim to strengthen the validity of the parallels drawn. The theory-based and interpretive medium- $n$ approach provides a synchronic and diachronic historical dialectic that investigates panoptic cycles in the development of Korean sovereignty as influenced by Eastern and Western thought from antiquity to the present.

For further research and theory development, the unique methodology of this articie offers a basis for cross-case analyses with countries that comparatively confront challenges to sovereignty with globalization. It likewise provides a conceptualization or re-conceptualization of current theory for quantitative studies and auxiliary qualitative research that employs a stronger use of primary sources. With insight from the epistemological foundations and psychology of their base assumptions, the current analysis simply identifies that ideas and beliefs in Western traditions of territorial sovereignty are not at all unlike their counterparts in Eastern philosophy. Respecting the sameness and difference between East and West while aiming to cultivate an awareness of the historical cycles, Korea illustrates aspects of the complex economic, political, social, and cultural transformations in relations. For an inward-looking society that historically remains passive amid invasion, the epistemological relationships enlighten the nature of the problems that one case confronts with change. To harmonize sovereignty with today's quixotic trends, new approaches prove necessary.

\section{THE HISTORICAL SEARCH FOR SOVEREIGNTY}

The foundations of cycles in Korean history, as well as the similarities between Eastern and Western experiences, reveal themselves with the earliest peninsular kingdoms. The developmental process of early Korean society from Neolithic times throughout the Bronze Cultural Era resulted in the emergence of three kingdoms on the peninsula. Before these three kingdoms, the ancient Choson ruled. Korean myths tell the folklore of Choson, based on the tale of a mythical tiger and bear, and the legend of Prince Tan gun born from the heavens. From Choson, the three distinct kingdoms evolved. Undisturbed by conflict, the cultural Paekche Kingdom of the southwest developed a well-organized government but lacked means to defend itself; since it needed to protect itself from China, the northern Koguryo Kingdom became more warlike (Joe and Choe, 1997). The third Silla Kingdom proved most influential in the early peninsular development of a social and political identity.

Increased Chinese aggression to intervene in the affairs of each kingdom motivated unity (Simmons, 1995). The southeastern Silla Kingdom (57 BCE-935 AD) initiated unification. The sophisticated Kingdom, when threatened by the Chinese, "endeavored with equal dynamism to attain the internal growth that was to bring about a new level of cultural synthesis $\cdots$ one of the most strenuous 
periods in the Korean history" (Joe and Choe, 1997, 42). Silla incorporated Buddhist and Confucian thought. Early Korean philosophy and epistemology ground themselves in the interpretation of the two traditions. Throughout its early history of ideas, the factionalism between them evinces to be not at all dissimilar to debates between rationalist and empiricist philosophers of Western political science.

Buddhist epistemology, related to Aristotle while, in particular, sharing much in common with empiricists from the Western Age of Reason and Enlightenment, advocates the primacy of the sensory perceptions. With knowledge acquisition and knowing grounded in an empiricist view of experiencing and perceiving (Bastow, 1997), it is pragmatic and cognitive with a moral philosophy reflecting Kantian thought unbound to classical, Western assumptions of science. Thus, Buddhism is equally Socratic and Gestalt oriented in its psychology. ${ }^{1}$ With a more Cartesian view, Confucian philosophy emphasizes reason and rationality of the mind over the sense perceptions. It also incorporates a historical dialectic like that of the Western philosophers Marx and-Hegel. Confucianism institutionalized itself while centered on the belief that bureaucracy, "by focusing on the concrete situations of institutional development and by delineating the nature of the changes, would enhance the understanding of practical statecraft and perpetuate the Confucian principles of government" (Franke, 1982); the same as the organizational bureaucratization of Western behaviorism. ${ }^{2}$

Literature on the policy implications of each philosophy illustrate that the subject undoubtedly proves complex (e.g., Hsu, 1975; Cheah, 2006), but the Eastern philosophies maintained divergent economic worldviews, involving complex interpretations equivalent to the way in which the Western economists adhere to assumptions held by political philosophers. While neither Eastern philosophy explicitly developed concepts of political or economic rights, the Buddhist frame of reference does emphasize the importance of social equity and equality. Government officials interpreted it with the belief that commercialism and free trade provide a means for achieving its values, advocating a form of social and economic rights without negative political rights. The underlying assumptions are thus comparable to the much later influence of empiricist philosophy on Western economic thought and the belief that liberal economies promote human rights, liberty, and freedom.

When exclusivity and economic inequality disenchanted the intellectual leaders of Silla, its governance disintegrated as the Kingdom laid the foundations for its replacement by the Koryo Dynasty (Joe and Choe, 1997). The objective for collective security failed as Silla fell from Chinese and Japanese threats and the tensions that arose between the factions of the former kingdoms (Joe and Choe, 1997). During the Koryo dynasty (918-1392), monetary and economic practices reflected early Buddhist policies; however, after the inequity of Silla, it and later dynasties sacrificed Buddhism for Confucianism. Economic inter- 
pretations of Confucianism did support capitalistic thinking throughout Asia (toward different ends and without any equivalent notion of rights). Nonetheless, beyond the Koryo dynasty, the influence of Confucianism in Korea advocated a mercantilist view of foreign trade.

Dynastic governance in Korean history borrows from the Chinese system, which is not unlike the political institutions influenced by Plato's Republic: hierarchical to the enlightened minds of the philosopher kings, or, in light of the Eastern reality, the Confucian philosophers. In later historical periods, they interpreted Confucianism with power political meanings. Overall, the introduction of the dynasty seemed to be a "mere superimposition of foreign institutions upon the ruins of Silla" (Joe and Choe, 1997, 156). While the Koryo Dynasty achieved prosperity, the centralization of power brought about a coup d'état in 1170 (Simmons, 1995), beginning a pattern of civil discontent and failed dynasties. The Eastern traditions suggested implicit concepts of sovereignty but relations, with issues concerning legitimacy, reflected the Western world before Westphalia (see Philpott, 1997). Although at different eras, as one might expect to be true of other civilizations throughout the medieval period, related patterns between the traditions thus reveal similarities.

While significant, as suggested, the comparisons remain complicated. Political and economic policies emerged from their doctrines, but Eastern philosophy originated with less politicizing than the way in which philosophers of Western thought politicized their thinking. Buddhism changed significantly with the institutionalization of the philosophy, becoming "a practice of following clearly articulated hierarchical structures providing centralized authority," which led to the subordination of monks in civil bureaucracy (Carter, 1997, 66-367). Given the complexities, historians of the Silla Dynasty, for example, often face criticism for their treatment of the political economy, leaving "modern historians with the difficult task of clarifying these enigmas through comparative analysis of Chinese and Japanese and other ancient societies" (Sun Kim, 2004, 95). How the philosophies become entangled, in a cycle of socio-cultural exchange, illustrates itself with the Korean search for sovereign legitimacy, the struggles to democratize, and obstacles to sustainable development.

\section{Unsolved Debates and the Continued Struggle}

Whereas each of the divergent philosophies faced differentiated obstacles in Korean governance, the Ch oe military regime (1149-1219) overthrew Koryo and repudiated them both. Substantial discontent with the social and economic problems of the royal dynasty surfaced. The military leader of the Koryo, Ch'oe Chung-heon seized control after consecutive rebellions and struggles for power, described as "a generation of kaleidoscopic successions of coups détats" (Joe and Choe 1997, 198). During a short period of three military dictatorships, the 
government radically reformed Korea and maintained power until the Mongol invasions. Targeting traditional doctrines, the Ch oe government betrayed conventions by attempting to solve the failures of Buddhist empiricism and Confucian rationalism, somewhat of a philosophical transposition where later but reciprocal ideation in the West became a catalyst for change. When the Mongols invaded China, they likewise dominated and ruled over the peninsula. Throughout this period, Confucianism underwent metamorphosis. Though brief, the $\mathrm{Ch}$ we reformatory spirit is one that had incarnated again. When the Chinese drove out the Mongols, remnants of Koryo's centralized administrative structures enabled transition to the Yi Dynasty (1392-1897), also known as the late Choson Dynasty.

Throughout Choson, the Chinese exercised an indifferent and benign reign over the peninsula (Joungwon, 1997). Confucianism deeply ingrained itself in Korean society during the era, which brought about a further decline in Buddhist influences and the commercial trade that sustained throughout Koryo. Buddhism suffered the loss of social respect and honor (Jae-ryong, 1999). A new Confucianism that surfaced, entangled with Mongolian thought, shares much in common with Western political realism and mercantilism (a correlation to be discussed with the state of affairs on the peninsula following the W/orld W/ars). Choson restricted international trade and evinces to be best characterized as an aristocratic and strict hierarchical order based on status (Karlsson, 2005), despite its historical criticism of Buddhist elitism. Needless to say, the Confucian influence in governance again disingenuously instituted itself in Korea and seemed imposed on their sovereign identity; however, the late Choson Dynasty sustained itself to become the longest in Korean history.

By the eighteenth century, the Dynasty witnessed a renaissance with substantial social and economic change, progress in science, technology, and agricultural productivity (Karlsson, 2005), but protectionist policies did not always prove entirely beneficial to development as the peninsula faced pandemic famines. Given corruption in the government tied to state-driven labor practices (Miller, 2007), into the nineteenth century, bureaucratic structures struggled to adjust to a changing world. With the onset of modernity, the economy faced problems with development, isolation, and decadence, which brought about its inevitable decline. When formal sovereignty established itself following the two World Wars and the Korean War, the same economic protectionism surfaced alongside communism. Including throughout an era of the late $\mathrm{Yi}$ Dynasty known as the 'Korean Enlightenment,' which attempted to define new directions, the history continues to illustrate the enduring struggles to adapt ideation, on behalf of a cosmology held universal in nature, to Korean culture.

\section{The Korean Enlightenment}

Following centuries of the late Choson Dynasty, the peninsula witnessed what 
became known as the Korean Enlightenment (1896-1910), an "intellectual experimentation and adaptation, as the leading intellectuals attempted to reconcile new ideas and models originating from the West" (Hwang, 2000, 1). During this period, Korean philosophers sought to interpret the ancient idea of kukka, meaning country or state, with the modern concept of sovereignty. As foreign relations encouraged new ideas and opportunities, with the situation awakening "the then slumbering community of Buddhism as well" (Jae-ryong, 1999, 25), interpretations emerged with two meanings: one maintaining that it constituted a collective people, the other equating it with the ruling authority of the elites (Hwang, 2000). 'Liberal' interpretations sought to challenge the traditional thinking, reflecting Buddhism. Buddhism upheld a belief in the equity of the collective but not entirely a democratic equality in the Western sense (see Arneson, 2002). The identification of kukka with the ruling political power of the nobility reflects Confucianism. The debates thus reveal differences corresponding to disputes over sovereignty between John Locke and Thomas Hobbes in Western thought.

As scholars sought to reconcile kttkea with Western political philosophy, given the positive right of Buddhist liberation philosophy (notwithstanding the lack of negative rights in the Eastern tradition and the deficiency of positive rights in the West), ideas included "political legitimacy, sovereignty, and even rights," (Hwang, 2000, 3, 21) as in a Lockean sense. Importantly, though, while labeling each Eastern philosophy as "religion" is debatable, they remain grounded in theological meanings and the political concept of separation of church and state had not established itself. Nevertheless, Locke's argument based on consent from the people (noting the complexities of Western individualism, the interactions between political and economic theory, patrician and even theocratic interpretations of Buddhism), did advocate a comparable notion of egalitarianism. Hobbesian sovereign authority incorporates concepts that are more vague; "the power of an absolute sovereign is, in that respect no different from any other political power arrangement" (Haworth, 2004, 93-94). Particularly as politics became authoritarian throughout the Mongolian era, Hobbesian philosophy, which construed Cartesian rationality, relates to power political interpretations of Confucianism.

Without having legitimized national sovereignty, the emergent Korean system suffered internally. At the same time, foreign commercial interests coveted opportunities in Korea as relations began to rival between Russia and Japan over the control of Manchuria (Joungwon, 1997). In 1882, the Korean government made its first treaty with a Western power, the United States, but developments, including the historical problems of an anarchic power balance with no central organization, became obstacles. Korea maintained neutrality as tensions escalated between Japan and Russia (Kim, 2007, 162). Interests conflicted until "the prospects for national independence seemed bleak, the search for sovereignty increasingly desperate" (Simmons, 1995, 121). Ten years after assuming control 
of Taiwan, Japan took possession of the Korean peninsula in order to continue with its imperialistic expansion.

While claims maintain the legality of the annexation, others argue that the Japanese forced the signing of treaties after their military surrounded the Kyongun 'gung palace (Tae-Jin, 1996). Focused primarily on its increased power and influence in European foreign affairs, the United States found itself in a weak position to achicve its intcrests in the Far East, thus, President Theodore Roosevelt "placated the Japanese by recognizing their hegemony over Korea and Formosa" (Chambers, 2000, 209-210). In doing so, Japan renounced any interest in the Philippines and appeased US relations in China. Both the Americans and British failed to understand the context of the incursion. Korean appeals, even given their treaty with the US, faltered without recognition of legitimate sovereignty.

The last attempts at reforming the late Choson Dynasty into a sovereign nation, under the pressures of foreign powers, failed. As Western influences began to affect the Korean reality, absent a system of checks and balances on power, a synthesis of the divergent traditions lingered in political theory without mechanisms to manage political differences. The history of ancient to early modern Korean society ends with Japanese imperialism. Korea remained under Japan's imperial rule until the end of the Second World War.

Throughout WWII, support for Korean independence surfaced with the belief that it would check further Japanese expansionism; these strategic motivations, with little knowledge of Korea and the Korean people. led to a political environment ill motivated and unprepared to manage affairs following Japanese surrender (Buzo 2006). Koreans had been "enmeshed in the humiliating and repressive matrix of Japanese racism"; the Japanese stripped the peninsula of its raw materials and agricultural goods (Simmons, 1995, 148-149). With Japan's imperialist policies modeled after British imperialism, Korea was to Japan as the first colony of the British Empire, Ireland, was to England (Calman, 1992). Given the nonzero-sum commercialism that distorted Korean society through a myriad of social and political interactions, itself transforming perceptions on state sovereignty, the historical period suggests critical questions over the changing nature of sovereignty today. Without legal sovereignty following the wars, many of the longstanding dilemmas in the governance of the Korean peninsula persisted while complicated by continued foreign interventions.

\section{THE MODERN SOVEREIGN STRUGGLE}

While the late nineteenth century promised a potential exchange of positive ideation, the interventions obscured the Korean reality. Imperialism weakened Korean legitimacy as a sovereign nation. Then, Western powers initiated designs 
for the peninsula before WWII ended. When the Cairo Declaration of 1943 sought to grant sovereignty and independence for former European colonies of the Imperial Age before the War (see Philpott, 1997), it also established the legal framework for Korea's independence. The Declaration aimed to restore governance to the Korean people "in due course." Instead, without Korean representation, the 1945 Yalta Agreement between the US and Soviet Union designed an agreement to put Korea under foreign trustccship. The Soviet Union previously played only a minor role in the Pacific. Yalta served to gain support from the Russians in the final phases of WWII.

Before Yalta, de facto Korean administrations emerged in the North and South, but sovereignty would not pass from Japanese control to the Koreans following the War. Although assistance in the war effort from the USSR ultimately proved unnecessary (because the Americans secured another means for ending the War), both the US and Soviet Union occupied the peninsula after Japanese surrender. The course of events thereafter remains complex. Nonetheless, non-zero-sum interests dominated as the coalitions demonstrated to be unsustainable and led to detrimental outcomes. Waking from colonialism, the tensions from foreign intervention since before the wars proved strenuous, not unlike those influences that brought forth unification at the time of the Silla Kingdom; but the Korean people would not achieve sovereign unity. The onset of Cold War strategy sacrificed unification. Foreign governments failed to assist the establishment of sovereign rule for a united people.

\section{Western Occupation and the De Facto Governments}

As war ended, with the Japanese accepting unconditional surrender, the Soviets entered Pyongyang to set up a military government in North Korea while US forces arrived and established the United States Military Government in Korea (USMGIK) in South Korea (Buzo, 2006). The respective leaders of the de facto governments that emerged were Kim IL Sung and Syngman Rhee. Sung served as communist leader against Japan and lived in Russia at the end of WWI. For involvement in the resistance, the Japanese also exiled Rhee, who fled to the US where he earned degrees from George Washington University, Harvard, and a Ph.D. in international law from Princeton; two factions that claimed to be the exiled government of Korea, one in China and the other in the US, identified Rhee as their leader (Joungwon, 1997). US officials, after changing their position of neutrality, also supported Rhee, believing he "was the right person to receive US support in Korea" (Lee, 2006, 49). The occupation, the emergence of these leaders, and subsequent events divided the political culture in ways unknown since before the Yi Dynasty. Already, with the sacrifice of its social foundations, the past resurfaced with Korean national sovereignty undermined. 
When the de facto governments clashed with the provisional military administrations that supported and worked against them, a range of events polarized the North and South. The strategic and administrative partitioning of Korea "was seldom if ever mentioned in the wartime discussions" (Simmons, 1995, 156); still, in the tug-of-war with a myriad of internal and external factors, the occupying powers allied for unity only inasmuch as it satisfied their national interests. Illustrating the obscurity and "often ephemerai nature of much World War II and early Cold War diplomacy," the two antagonistic Koreas emerged from the mirrors of their respective sponsors (Buzo, 2006, 67-68). Many questions remain over the division; 3 nevertheless, scholars generally attribute the foreign interventions and uneven patterns of development as the key causes. The occupiers of the peninsula attempted to correct the situation, but politics had already divided into a non-zero-sum game.

South Korean President Syngman Rhec (1948-1960) did aim to establish a governing structure patterned after that of the United States with executive, legislative, and judicial branches and a system of checks and balances. Without explicit synthesis of Eastern and Western models, it sought consolidation of sovereignty redolent of the way that the Korean Enlightenment guided efforts to develop a philosophy based on ideation from Western thought. With sharp criticism, reflecting the dilemmas of Confucianism, Rhee's efforts in practice linger with the attempt to establish a democratic system through radically undemocratic means. The political base dominated through bureaucracy and coercion, "virtually uncontrollable outside its ranks $\cdots$; dramatic example of an attempt by a masterful political manipulator to establish and consolidate a new political system in a society with very weak developmental bases" Joungwon, 1997. 115-116). Consequently, as with previous ideologies, the American model seemed imposed. Within its zone of proximal development, Korean society failed to internalize the positive as the negative divided it.

Rather than providing a base to establish a sustainable Silla unification of the peninsula and the necessary balance of power, the Rhee administration instead resembled the traditions of the Koryo or late Choson Dynasty. Through a centralized bureaucracy, Koryo "committed itself to the wholesale adaptation of the Chinese political institutions to the Koryo reality" (Joe and Choe, 1997, 142), drawing from a Confucianism like $\mathrm{Yi}$, which emphasized a strong legal order to support hierarchical power in much the same way Rhee's government operated. Though Rhee fell out of favor in securing leadership, the US continued to support him "to head the puppet government" (Simmons, 2005, 166) when the responsibility to establish a unified regime transferred to the United Nations. ${ }^{4}$ By 1948 , the UN intervention to formalize governance also failed. The conflicts resulted in two independent sovereign nations that eventually further legitimized their differences and separation through war. 


\section{The Sovereign Split Drawn on the Map}

Between 1948 and 1950, antagonisms escalated with "inflammatory rhetoric, subversion, insurrection, and guerilla warfare" (Buzo, 2006, 141). The South began to become viewed as tyrannous and sustained only by subjugation and US aid; peasant uprisings and clashes along the $38^{\text {th }}$ parallel frequently upset the North (Simmons, 2005). Eventually, the Korean War (1950-1953) began and cemented the country's divisions. For the Korean people, in addition to the political and economic consequences, the separation resulted in enormous social and cultural sacrifices. It reinforced the sovereign legitimacy of each government as its escalation was catalyst in Cold War tensions between the US and the Soviet Union. The war did not end in a treaty and the sovereign borders drawn remain today.

The challenges to sovereignty from early Korean political culture throughout the Enlightenment to the turn of the century still linger. Weakly regulated, the corrupt Rhee government struggled and then collapsed by the 1960s. The attempts to introduce a second republic "illustrated dramatically those aspects of Korean political behavior inherited from the traditional era which most need alteration before an effective developmental system may be constructed" (Joungwon, 1997, 202). Subsequently, a new government sought power but military forces overthrew it in a coup détat within a year. The Enlightenment ideal, in cultural synthesis during the late nineteenth century, interrupted by Japanese imperialism and modeled after the US government following, thereafter faced Ch oe-like resurgences.

The Park Chung-hee administration (1963-1979) that consolidated from the coup proved less than ideal, much less democratic. Establishing itself within an environment and through means not unlike the solutions sought by the ancient $\mathrm{Ch}$ 'oe government, the militantly hierarchical Park administration pursued a distorted version of neo-mercantilist policies through the import substitution that the Rhee government first instituted (see Kim, 1997, 85-86). With aid to Korea, the United States set conditions for the military regime, including the return of sovereignty to a civilian government by 1963; it was not until the 1980 s that the military government met its goals, then fell (Joungwon 1997). Nevertheless, supported by Soviet aid and without the obstacles to governance that the South experienced, the North embodies the dictatorial solution to anarchy more than its counterpart did.

\section{KOREAN SOVEREIGNTY FOLLOWING THE WAR}

With the two governments recognized as separate sovereign nations, Korea throughout the twentieth century endures in a cycle with the same barriers 
to governance that the peninsula has known since antiquity. The dilemmas are not particular to the Korean experience; they do illustrate central tensions. With sovereignty split, each supported by Cold War rivals, the Koreas illustrate differentiated aspects of the cleavages with Confucian governance or the Hobbesian dilemma. Including the problems of protectionism, the correlations also reflect upon the Mongolian influence in the region's political culture.

The Hobbesian dilemma reters to the paradoxes of sovereignty first noted by the political thinker Hobbes, whose "disturbingly pessimistic view of human nature" led the philosopher to employ a strict deductive method with a mechanistic view of mind and nature from the individual in society to government, perceived as a science based on power (Battigelli, 1998, 40-55). Hobbes emphasized the need for a strong, state-centered system with the aim of maximizing political power to maintain order and security in a natural, anarchic international system with no higher power or authority. Confucianism at its origins, while strictly hierarchical at its core, did repudiate Mongolian hegemony based on military force, which it viewed as barbaric; however, following the Mongols, it emphasized a strong legal authority and military prowess to coerce and maintain a social organization through the exercise of power (Langlois 1992). Perceived as rational, the relationship between dilemmas with Confucianism and Hobbesian thought thus proves to be quite distinctive.

In view of the Western reality, the great irony is that the two political frames diametrically opposed throughout the Cold War, by way of their ideological underpinnings to protect sovereignty in a state of nature, share comparable assumptions. The historical thought resembles contemporary American theorists. For example, Kenneth Waltz maintains "the state is sovereign means that it decides for itself how it will cope with its internal and external problems"; others such as Robert Gilpin suggest "the state is sovereign in that it must answer to no higher authority in the international sphere" (Ashley 1986, 273). While North Korea exemplifies the dangers of the Hobbesian dilemma, economic policies following the two world wars demonstrate the persistent obstacles of protectionism in the South.

\section{The Hobbesian Dilemma: North Korea}

In terms of Korean political history, even more than the Park government has noted, North Korea likens to a resurgence of the $\mathrm{Ch}^{\prime}$ oe solution to the sovereign dilemma, and a radical, socialist resurgence at that. Building military relations through bureaucratic institutions, Ch oe repudiated the cultural foundations to governance during Silla and Koryo in much the same way North Korea remains at odds with the South. Nonetheless, with Confucianism ingrained in Korean society, Mongolian influences and predicaments persist with severe hazards. As the US did for the South, the Soviet Union provided the North Korean 
state with political and economic support. The Soviets certainly affected East Germany more than North Korea, as Pyongyang held close ties with China and relations become complicated into the 1960 s with the Sino-Soviet split; but the North lost a valuable ally as the Cold War ended.

When the USSR collapsed, the North confronted problems with its political and economic policies as it "could no longer pay for its needs for food, raw materiais $\cdots$ (and) advanced capital equipment and military hardware" (Buzo 2006, 149). With the changing currents, the sovereign nation soon found itself at odds with the rapidly transforming politics and economy of the international system. Remarkably, the North survived the collapse of the Soviet Union. However, in the post-Cold War environment, the order the state claims to create sustains itself through psychological controls and behavioral conditioning. Believing to act in rational interests of organization, the "coercive power at hand the state is not only a source of protection of the population; it is also a source of threat" (Sorensen 1986, 903). The endgame thus results in "predatory, oppressive states that are a danger to world order" (Keohane, 2002, 11), as in the case of North Korea's threat to global security. In an anarchic international order rivaled by competing organizational interests, the tribulations of power and the Hobbesian dilemma remain as Pyongyang strengthens its ties with China.

The predicament lingers with the fact that while "it might be possible momentarily to establish an orderly social aggregate," hegemonic consolidation of power lacks sustainability (Keohane, 2002, 278). Moreover, "sophisticated advocates of republican liberalism, such as Kant, acknowledge that even well-constituted republics can be warlike"; the historical solution to Hobbes's dilemma, "at the internal level," has been constitutional government and "reliable representative institutions, with checks on the power of rulers" (Keohane, 2002, 68). Power balancing-failing to be realized during the Korean Enlightenment, not fully instituting themselves in the South until the late 1990s, and lacking in international political and economic organization-gave conservative thinkers of the Western Enlightenment confidence in democratic governance. The radical bearing of the North Korean government does remain at difference to South Korea following the Korean War, but obstacles in the South certainly prove to be relevant. While the North illustrates the dangers of the Hobbesian worldview, the post-war South also reveals another aspect of the dilemma. South Korea provides evidence of the economic predicament of protectionism in governance.

\section{The Protectionist Economy of the South}

The historical record illustrates that state centrism and protectionism from interactions, as inaction itself becomes an interaction, results in economic barriers for the domestic state. For South Korea, sustainability again faltered due in part to the policies that earned the peninsula's reputation for being known 
as the 'Hermit Kingdom' from the time of the Yi Dynasty. Hence, it likewise faced challenges to sustainability on the economic side of the paradox. Again, the Park administration illustrates the social and political obstacles of the bureaucratic dynasty for development. In the South, Park maintained that he achieved the values of Korean democracy that scholars sought to advance and theorize throughout the Enlightenment period. Instead, like Rhee, politics reflected governance comparable to that of antiquity before and following the kaleidoscopic revolutions and Mongolian invasion.

With aims to strengthen national defense and development through a familiar Korean bureaucracy and military leadership, the Park administration coerced order through a mindset habituated by Confucianism. Like the breakdown of relations in the North with the Soviet Union, the Nixon administration lessened support to the South as the United States sought to improve relations with China as early as the 1970 s, from which, South Korea initiated relations with Japan for security arrangements (Kim, 2007). Such relations proved complicated, as they do today, given Korea's convoluted history with Japan (a country itself with a quite different post-WWII identity). Following Park, the country appeared destined to endure in a cycle associated with the dynastic system: internal problems result in a toppling of the government only to be replaced by another decadent system; then overthrown again after it spiraled in decline (Joungwon, 1997). In 1979, after Park's assassination, the South again came under martial law. When it returned to civil rule, no new leadership emerged and Korea faced challenges that led to the collapse of the Yi Dynasty (Joungwon, 1997). With the latest reforms, South Korea attempted to break from the cycle only to face another dilemma known to its history, that of the inequities of liberalization.

Noted in detailing the history of the peninsula, at the border of their shared histories and demarcated by a line that veiled their similarities, the split of Korea into two independent states exemplifies a mutual predicament. While the South sought change with the increase of globalism, exigent problems concerning opposing tensions between the state and the market that sacrifice sovereignty, national security, social and cultural development remain. Neoliberal economics cannot claim to solve the challenges. The resulting paradox illustrates a liberal dilemma that develops from classical, liberal economics and neoliberalism today.

\section{ECONOMIC DILEMMAS WITH GLOBALISM}

South Korean policymakers believed nationalist, regulatory, and state driven economic policies to be ineffective in a complex global economy. Thus, based on faith in market efficiency, the new "replaced the old government-driven development policies"; Korea opened its markets, joining the WTO and the OECD, accepting globalism as its "leading governing ideology $\cdots$ in which 
globalization and liberalization supersede national boundaries" (Kim and Hong, $2001,78-79)$. The reforms brought the country respectable success and recognition. Aided by technology, the global economic driver, South Korea quickly globalized as the country boasted high literacy rates and high percentages of homes with access to information, products and services that gave consumers purchasing power. The successes are reminiscent of trade practices under the Silla and policies in statecraft with Buddhism that brought unprecedented prosperity to Koryo with its noted, "business acumen and diversified commercial adventures" (Joe and Choe, 1997, 166). The historical and modern experiences illustrate the complex issues entangled in the dynamics of sovereignty.

The developmental policies gave the South Korean economy the status of being one among the East Asian Tigers that lifted themselves from the Third World to become the world's strongest newly industrialized nations-states. Reforms, actually underway since the 1970 s, appear to be the catalyst of their recent achievements. However, not until the turn of the twenty first century with the newly elected president, Kim Dae-jung (1998-2003), did the policies encourage increased democratization (Goldstein, 2004). Rather than General Park's claims, Kim Dae Jung began to achieve what scholars of the Korean Enlightenment and Rhee later aimed to accomplish. As with the thought of Kim Ok-Kyung, Pak Eun-Shik and others throughout the nineteenth century that contested the Confucian feudalistic model of government to "establish freedom and autonomy for all Korean people" (Minhong, 1978, 227), economic liberalism today challenges the Confucian mindset and protectionism advocated by previous dynasties and the military governments. Moreover, unlike earlier attempts at reform, the recent South Korean liberal reforms brought greater respect for human rights and humanitarianism; as exemplified by Kim Dae-jung's Sunshine Policy toward the North and the pro-human rights legislation passed to ensure an effective democracy.

The economic policies often serve as a theoretical justification of globalization, neoliberal and institutional claims for internationalism. From the critique of military force and hegemonic power, liberal theories maintain trade and organizations create shared values for collective action and solve the internal dilemmas of mercantilism and the Hobbesian state of nature (see Pease, 2009). Liberalism holds the belief that liberal economies support democracy and rights; that, with the institutions to support them, strategies like those employed in Korea involve a zero-sum game that promote prosperity and peace.

However, as with ancient influences that interpreted the Buddhist virtues of social equality and the belief that commercialism supports such virtues, the outcome is the problem of openness in the domestic sphere. Neoliberalism harbors social and ecological consequences: "repression has disenfranchised the middle classes, has alienated the poor from its 'economic miracle' built on their backs, and has caused a collapse of the agricultural sector and environmental degradation 
that chokes off further growth" (Hoogvelt, 1997, 214). While the success reflects those of other regional countries, the uphill task of lifting populations above subsistence levels proves to be a harsh process of development with problems of elitism stretching across regional boundaries (Hoogvelt, 1997). In the same way that the exclusivity of Buddhism disenchanted the perceived values of commercialism and free trade throughout earlier epochs, neoliberalism and globalism sacrifices critical issucs.

While the case of South Korea provides some evidence for the claim that economic liberalization supports democratization and human rights, it would be fallacious to believe that the ends justify the means. There remains much to be seen from the example of Korean development. Furthermore, South Korea -as well as the other successes with globalism, including the fifth tiger Ireland -benefited from a stronger state driven economy than commonly recognized, which complicates economic relations. Much the same as policies advocated during Koryo and Silla, equally where historians confront the task of advancing an investigation of state interventionism during these eras (Kim 2004), here are the philosophical complexities at intersections between politics and economics then and now.

Even during late Choson, a market system developed to offset the failures and explore alternatives to state centrism, "which in turn led to conflict with those social groups that had to bear the burden" (Karlsson 2005, 585). Liberalization results in a reverse of the Hobbesian dilemma, problems that protectionism as well as the dynastic system historically sought to solve. Interactions between globalizing forces and the sovereign nation-state prove greatly more complex than advocates of integration and globalism recognize. Case in point is the Asian Financial Crisis and the consequences for Korea and the region as a whole.

\section{The Asian Financial Crisis}

When the 1997 Asian Financial Crisis hit, Korea was among those nations that experienced firsthand the economic, social, and political consequences ( $\mathrm{Ha}$ and Kim, 2007). It became one of "the greatest shocks the region and the world's economic and business systems had ever experienced" (Yip, 2000, 375), compared to the consequences of laissez-faire economics with the worldwide depression that followed the first of the two World Wars. With some believing that it created a "social dislocation comparable to war," it stands as a disaster second only to the Korean War ( $\mathrm{Ha}$ and Kim, 2007, 60). The outcomes of the Asian Financial Crisis serve as a sobering critique of globalism and the institutions that aim to support it.

In November of 1997, the International Monetary Fund (IMF) took control of the South Korean economy as economic officials mandated open markets for trade and investment. By the end of 1997, Korea devalued its currency 
by 20 percent, its stock markets were collapsing, and its banks became "saddled in $\$ 50$ billion in bad loans based on cronyism" (Goldstein, 2004, 472). When the IMF intervened, nationalists called the day that they accepted the agreement a 'Day of National Humiliation' (Kim and Hong, 2001), resurfacing memories of the colonial past and interventions polluted by the same sacrifices that Korea experienced throughout history.

The Korean people did not welcome globalization before the collapse; now, liberalization seemed even more imposed by an organization that many believe negatively propels globalization through "massive privatization, deregulation, acceleration of international trade and capital transfer, the promotion of mergers and acquisitions, and finally the enhancement of economic interdependence around the world" (Kim and Hong, 2001, 90). Interventions pushed the government to reduce the "many restrictive regulations that impede achieving international competitiveness" (Yip, 2000, 81) as the IMF and World Bank insisted on openness from the economy and the people felt the burden of the consequences.

Globalization reflects equivalent forces that historically challenged Korean sovereignty. The same economic conflicts arose from ancient trade relations between China and Japan. Each gained the political power to coerce non-zero-sum economic conditions. During Silla, foreign trade in time became "overshadowed in value and importance by non-official commerce" [commerce not directly sanctioned by the state in order to benefit the state]; then, as private trade flourished, the central government weakened from internal politics (Joe and Choe, 1997. 126-128). Early Koryo burgeoned with comparable interests, but the downsides remain evident. With the credit packages from Western and Japanese banks and "risky lending with moral hazards" ( $\mathrm{Ha}$ and Kim, 2003, 63), while not as extreme as historical intrusions from the Mongolian invasion to Japanese imperialism, the disadvantages risked consequences of dependency for Korea, which being different to interdependence, sacrifices national sovereignty and political self-determination.

Without the aid of the IMF, one might expect South Korea could have endured more brutal consequences, but the case illustrates the problems of liberalization without sufficient solutions to the potential hazards of globalization; thus resulting in the negative impact of dependency and colonialism. Dependence involves a situation where "rich regions need to loan out their money just as poor ones need to borrow it-but it is a transnational interdependence with an extreme power imbalance reflecting imperialism" (Goldstein, 2004, 472). For a nation that often represents the success of economic development with globalism, the compromising dependence risks subordination to transnational forces. Hence, the economic dilemmas of Western ideation procure fallacies similar to historical interpretations of Buddhism. The value of institutions cannot be undermined, but neither can they efficiently manage the international system without advancing an effective means of supporting increased globalism (Burke, 2009). Liberalism 
"favors greater openness and the institutions needed to assure openness" (Keohane 2002, 10), but its practice remains complicated where there remains a need to address the domestic and international complexities of sovereignty.

\section{CONCLUSION}

Korea continues to face dilemmas that throughout history concern critical debates in political and economic philosophy, thus facing the need to reconcile two incompatible theories of sovereignty. One tradition is of protectionism and nationalism that risks economic and political collapse, while the other erodes and sacrifices national sovereignty. The debates over sovereignty reflect the same in the West, which, at a time of increased international interactions, need be understood and solved through new ways of thinking and perceiving.

The limits of a sustainable civil society and sovereign governance based on Confucianism prove evident in the history of Korea. In comparative analysis, the underlying assumptions of its ancient philosophy, as influenced by Mongolian thought, relates to the Western dilemmas of protectionism and political realism. From which, the Souch came to face the incvitable decadence of protectionism while the radical North emerged as a threat to the international system. The mercantilism of the South Korean economy-the traditional 'Korean-way' to development-deteriorated at the end of the Cold War. Nevertheless, leading to the sacrifice of self-government, historic and contemporary interpretations of 'liberal' philosophy do not entirely provide a reliable solution. As such, it is not surprising that "debates about openness often $\cdots$ divide the traditional right as well as the traditional left" (Keohane 2002, 11). The results with increased globalism are tensions between state and market and emblematic obstacles to national sovereignty from increased liberalization.

The consequences compare to those of Korean antiquity, resulting in self-fulfilling cycles to the extent that there remains the need for new theoretical lenses in order to advance beyond them. With some irony, as neoliberalism aims to problem-solve the protectionist Korean economy in the same way that developed countries seek alternatives to state-centered policies, equivalent issues with the inequities resulting from interpretations of Buddhism became the very reason it lost prestige and influence in Korea. However, power political relations-as forthcoming with China's rise in military and economic power-do not resolve the lack of efficient institutions in relations. Reliable solutions need be sought in order to develop and expand knowledge of the way in which social interactions affect sovereignty through new ways of seeing, perceiving, and respecting the traditions of the past.

Today, for example, Buddhism seeks a path at difference to their former entanglements with politics and economics and focuses concerns on "providing economic 
relief for the poor in seeking international understanding, interreligious colloquia and peace" (Carter, 1997, 368). Encouraging debate over the interpretations and conclusions drawn in the current research, further research need concern itself with a continued examination of the influences from each tradition. The holistic case-within-case and interdisciplinary analysis of Korean history and its cultural developments, alongside the epistemologies and assumptions of Eastern and Western traditions, offers a foundation from which debate and more in-depth studies might develop. Neither divergent philosophy dependably solves the dilemmas that result from each; but, from the sameness and differences between them, East and West can attain epistemological unity. Through this, Korea's sovereign identity need not be lost in the kaleidoscope of globalism, but the sum of the history does lead one to recognize the need to consider a rethinking of the roles of the tiger and the bear in the ancient Korean myth.

\section{REFERENCES}

Arneson, Richard J. 2002. Equality. In The Blackuell Guide to Social and Political Philosophy, ed. Robert L. Simon. Malden: Blackwell Publishing Ltd.: 85-105.

Ash, Mitchell G. 2005. Gestalt Psychology in German culture. 1890-1967. New York: Cambridge University Press.

Ashley, Richard K. 1986. The Poverty of Neorealism. In Neorealism and its Cirtics. ed. Robert Keohane. New York: Columbia University Press: 225-300.

Bastow, David. 1997. Rationality in Buddhist Thought. In A Companion to World Philosophies, eds. Eliot Deutsch and Ronald Bontekoe. Malden: Blackwell Publishing Ltd.: 410-419.

Burke, Kenneth M. 2009. Global Politics of the Mind: Constructivism in education and international political theory. Saarbrucken: VDM Verlag.

Buzo, Adriane. 2002. The Making of Modern Korea. London: Routledge.

Calman, Donald. 1992. The nature and origins of Japanese imperialism: a reinterpretation of the great crisis of 1873 . London: Routledge.

Carter, John R. 1997. Reflections on social and political ideals in Buddhist philosophy. In A Companion to World Philosophies, eds. Eliot Deutsch and Ronald Bontekoe. Malden: Blackwell Publishing Ltd.: 360-369.

Chambers, John W. 2000. The Tyranny of Change: America in the Progressive Era, 1890-1920. New Brunswick: Rutgers University Press.

Chean, Pheng. 2006. Inbuman Conditions: On Cosmopolitanism and Human Rights. Cambridge, Mass: Harvard University Press.

Cox, Robert W. 1986. Social Forces, States and World Orders. In Neorealism and its Critics, ed. Robert Keohane. New York: Columbia University Press: 204-254.

Franke, Herbert. 1982. Chu Hsi and Yuan Neo-Confucianism. In Yuan Thought: 
Chinese Thought and Religion under the Mongols, eds. Hok-Lam Chan and W. Theodore De Bary. New York: Columbia University Press.

Goldstein, Joshua S. 2004. International Relations. New York: Longman.

Ha, Yong-Chool and Taehyun Kim. 2003. Lessons from the Asian Economic Crisis: A View from South Korea. Cambridge Review of Intemational Affairs 16(1): 59-70.

Hammond, Debora. 2003. The Science of Synthesis: Exploring the Social liniplicalions of General Systems Theory. Boulder: University of Colorado Press.

Haworth, Alan. 2004. Understanding the Political Philosophers: From Ancient to Modern Times. London: Routledge.

Hoogvelt, Ankie. 1997. Globalization and the Postcolonial World: The New Political Economy of Development. Maryland: John Hopkins University Press.

Hsu, Leonard Shih-lien. 1975. The Political Pbilosophy of Confucianism: an interpretation of the social and political ideas of Confucius, bis forerumners. and his early disciples. London: Cruzon Press.

Hunt, Morton. 1993. The Story of Psychology. New York: Doubleday.

Hwang, K. M. 2000. Country or State? Reconceptualizing Kukka in the Korean Enlightenment Period, 1896-1910. Korean Surdies 24: 1-24.

Jae-ryong. Shim. 1999. Korean Buddbism: Tradition and Transformation. Seoul: Jimoondang Publishing Company.

Joe, Wanne J. and A. Hongkyu Choe. 1997. Traditional Korea: A Cultural History. New Jersey: Hollym.

Joungwon, Alexander K. 1997. Divided Korta: The Politics of Development. New Jersey: Hollym.

Karlsson, Anders. 2003. Famine. Finance and Political Power: Crop Failure and Land-Tax Exemptions in Late Eighteenth-Century Choson Korea. Journal of the Economic and Social History of the Orient 48(4): 552-592.

Keohane, Robert. 2002. Power and Governance in a Partially Globalized World. London: Routledge.

Kim, Daeho and Seok-Kyeong Hong. 2001. The IMF, Globalization, and the Changes in the Media Power Structure in South Korea. In Media and Globalization: Why State Matters, eds. Nancy Morris and Silvio Waisbrod. New York: Littlefield: 77-92.

Kim, Kwan S. 1997. From neo-mercantilism to globalism: the changing role of the state and South Korea's economic prowess. In The Rise of East Asia: critical visions of the Pacific century, eds. Mark T. Berger and Douglas A. Borer. London: Routledge.

Kim, Seung-young. 2007. Japanese diplomacy towards Korea in multipolarity: history and trend. Cambridge Review of International Affairs 20(1): 159-178. Langlois, John D. 1982. Law, Statecraft, and the Spring and Autumn Annals in Yuan Political thought. In Yuan Thought: Chinese Thought and Religion under the Mongols, eds. Hok-Lam Chan and W. Theodore De Bary. New York: Columbia 
University Press: 89-152.

Lee, Jongsoo J. 2006. The Partition of Korea After World War II: A Global History. New York: Palgrave Macmillan.

Miller, Owens. 2007. Ties of Labour and Ties of Commerce: Corvee Among Seoul Merchants in the Late 19th Century. Journal of the Economic and Social History of the Orient 50(1): 41-71.

Minliong, Choe. 1978. A modern bistory of Korran pbilosophy Scoul: Seong Moon $\mathrm{Sa}$.

Philpott, Daniel. 1997. Ideas and the Evolution of Sovereignty. In State Sovereignty: Change and persistence in international relations, ed. Sohail H. Hashimi. University Park: Pennsylvania University Press: 15-48.

Simons, Geoff. 1995. Korea: The Search for Sovereignty. London: Macmillan Press.

Sorensen, Georg. 1986. Development as a Hobbesian dilemma. Third World Quaterly 17(3): 903-916.

Sun Kim, Chong. 2004. Silla Economy and Society. Korean Studies 28(1): 75-104.

Tae Jin, Yi. 1996. The Illegality of the Forced Treaties Leading to Japan's Annexation of the Great Han Empire. Korean National Commission for UNESCO 36(4): 55-85. 


\section{ENDNOTES}

Gestalt psychology developed during the early history of Western psychology. See Ash (2005) for a history and analysis of the science of Gestalt.

Behaviorism in the West, specifically in the United States, institutionalized throughout the turn of the twentieth century as behavioral schools of psychology reigned in a history of ideas following the tradition of Emile Durkheim's sociology and Max Weber's organizational theory. The history of the influence of behaviorism in numerous disciplines can be found in Hammond (2003). The history of psychology from Hunt (1993) details earlier foundations for behaviorism and proves a valuabie reference on Western psychology.

Each providing analysis of the events, Joungwon offers detail on the domestic environment in Divided Korea while Lee analyzes diplomatic politics in The Partition of Korea.

Full analysis of UN involvement is itself discussed by Lee in The Partition of Korea. 